\title{
PEMETAAN DINAMIKA HUTAN MANGROVE MENGGUNAKAN DRONE DAN PENGINDERAAN JAUH DI P. RAMBUT, KEPULAUAN SERIBU
}

\author{
MAPPING OF MANGROVE FOREST DYNAMICS USING DRONE \\ AND REMOTE SENSING IN RAMBUT ISLAND, SERIBU ISLANDS
}

\author{
Hadiwijaya Lesmana Salim, Restu Nur Afi Ati dan Terry Louise Kepel
}

Pusat Riset Kelautan, Badan Riset dan Sumberdaya Manusia Kelautan dan Perikanan, KKP Kompleks Bina Samudera, Jl.Pasir Putih 1 Ancol Timur, Jakarta, Telp:(021)64700755 Faks: (021)64711654 E-mail: hadi2804@gmail.com

Diterima tanggal: 14 Februari 2018 ; diterima setelah perbaikan: 11 Juli 2018 ; Disetujui tanggal: 08 Agustus 2018

\begin{abstract}
ABSTRAK
Pengamatan sebaran dan luas hutan mangrove di Pulau Rambut telah dilakukan pada bulan November 2017 dan Juli 2010 dengan menggunakan analisis foto udara dan citra Geo Eye 1. Kunjungan lapang dilakukan untuk validasi lapang. Metode yang digunakan dalam penelitian ini adalah segementasi dan klasifikasi terbimbing menggunakan metode analisis berbasis objek (OBIA). Hasil analisis foto udara, data citra dan validasi data pengamatan lapangan, diestimasi bahwa sebaran dan luas hutan mangrove di Pulau Rambut adalah 16,73 ha untuk tahun 2010 dan 17,48 ha di tahun 2017 atau terjadi penambahan sebesar 0,75 ha. Mangrove di P. Rambut terdapat 10 jenis dan didominasi oleh rhizophora mucronata. Hasil penelitian menunjukkan bahwa analisis dijital berbasis objek terhadap foto udara hasil akuisisi menggunakan drone memberikan hasil yang lebih baik untuk pemetaan dinamika hutan mangrove jika dibandingkan dengan penggunaan citra satelit Geo Eye 1, dengan akurasi keseluruhan sebesar 77,3\% dan nilai koefisien kappa sebesar 0,62.
\end{abstract}

Kata kunci: Mangrove, drone, penginderaan jauh, Pulau Rambut, OBIA.

\section{ABSTRACT}

Researched of mangrove forest in Rambut Island, Seribu Islands was carried out on November 2017 and July 2010 using aerial photogrammetry and Geo Eye 1 imagery analysis. Field visit was done to validate the result. Segmentation and Supervised Classification method was done using object based image analysis method (OBIA). Aerial photogrammetry and Geo Eye 1magery Analysis and data validation from field survey, it is estimated that distribution and areas of mangrove forest in Rambut Island in 2010 is 16.73 ha and 17.48 ha in 2017. There is an additional area of 0.75 ha during 7 years. Mangrove in Rambut Island consist of 8 species and dominated by rhizophora apiculata and rhizophora mucronata (Onrizal \& Kusmana, 2006). The results showed that objectbased digital analysis of aerial photographs which acquisited using drones gave better results for mangrove forest dynamics mapping compared to the use of satellite imagery of GeoEye 1, with an overall accuracy of $77.3 \%$ and a kappa coefficient of 0.62 .

Keywords: Mangrove, drone, remote sensing, Rambut Island, OBIA. 


\section{PENDAHULUAN}

Pemanfaatan citra satelit untuk pemetaan dinamika hutan mangrove telah banyak dilakukan seperti yang telah dilakukan oleh Suwargana (2008) yang menganalisis perubahan hutan mangrove di Muara Gembong, Bekasi dan Suprakto (2005) yang telah mengkaji dinamika hutan mangrove di pesisir selatan Kabupaten Pamekasan. Beberapa institusi baik pemerintah maupun swasta yang membutuhkan data spasial telah banyak menggunakan teknologi tersebut. Hal tersebut dikarenakan oleh beberapa keuntungan diantaranya kemampuan resolusi temporal dan spasial (Puntodewo et al., 2003) yang bisa diandalkan sehingga dapat diandalkan untuk melakukan pengawasan permukaan bumi dalam tingkat kedetailan tertentu. Terlebih lagi harga yang murah atau bahkan gratis dan dapat mencakup area yang luas (Somantri, 2008) dan (Septiana et al., 2017). Beberapa website menyediakan data penginderaan jauh yang gratis, misalnya USGS, dan untuk resolusi tinggi dapat diperoleh dari Google Earth.

Selain citra satelit, foto udara telah juga sering digunakan untuk pemetaan penggunaan lahan (Amelia et al., 2015). Foto udara merupakan citra foto yang diperoleh dari survei udara menggunakan pesawat baik berawak ataupun nir-awak yang mengudara diatas permukaan bumi pada ketinggian yang rendah (Gulartso et al., 2013). Dikarenakan kemampuannya untuk terbang pada ketinggian yang rendah, resolusi foto yang diperolah dapat sangat detail yaitu kurang dari $25 \mathrm{~cm}$ per piksel (Ramadhani et al., 2015). GSD sebesar 4,3 cm per piksel dapat diperoleh ketika tinggi terbang setinggi 100 meter.

Data yang diperoleh dari citra satelit dan foto udara merupakan data dasar yang perlu diolah dan diintegrasikan ke dalam sebuah sistem yang dapat mengelola, menganalisis dan menampilkan informasi keruangan (spasial) yang disebut Sistem Informasi Geografis (Huisman \& Rolf, A. De. By, 2009). Pengaturan informasi-informasi spasial disajikan dalam suatu tematik unsur yang disebut layer. Layerlayer tersebut yang nantinya ditampilkan dan dilakukan analisis keruangan untuk menghasilkan informasi baru yang menyangkut obyek spasial di permukaan bumi.

Penerapan aplikasi citra satelit dan foto udara yang diintegrasikan dengan sistem informasi geografis adalah pemetaan dinamika luas hutan mangrove. Hutan mangrove sebagai bagian dari tutupan lahan menggambarkan aktivitas manusia di permukaan bumi dalam kaitannya dengan pemanfaatan lahan (Purbowaseso, 1995). Pemetaan tutupan lahan menurut Lo (1995) sangat berhubungan dengan kajian vegetasi, tanaman pertanian dan tanah dari permukaan bumi dan juga hasil budaya manusia unsur buatan seperti permukiman dan utilitas lahan. Hal tersebut akan menentukan pola bagaimana sebaran dan dinamika tutupan lahannya.

Data penggunaan dan tutupan lahan sangat penting untuk sebuah perencanaan (Muhammad, 2014). Data tersebut sangat bermanfaat untuk mengidentifikasi kesesuaian lahan, alternatif dan pemilihan penggunaan lahan yang lebih baik, bahkan sampai dengan perencanaan untuk perubahan lahan. Keunikan penggunaan lahan di suatu daerah pun harus diperhatikan, karena berbeda daerah tentu akan berbeda pula karakteristiknya. Sehingga proses perencanaan pembangunan pun akan berbeda. Data spasial yang akurat dapat diperoleh melalui pengintegrasian yang terpadu antara data penginderaan jauh dengan sistem informasi geografis (Wahyunto, 2007). Beberapa penelitian menunjukkan bahwa pengintegrasiannya tersebut dapat meningkatkan keakuratan data (Sitorus et al., 2006).

Lokasi penelitian adalah Pulau Rambut di Kepulauan Seribu, DKI Jakarta. Pulau Rambut merupakan salah satu situs Ramsar yang ditetapkan sejak tanggal 11 November 2011. Situs Ramsar merupakan situs yang telah ditetapkan oleh sekitar $90 \%$ seluruh Negara anggota PBB untuk melindungi kelestarian dan lahan basah di seluruh dunia. Melalui Konvensi Ramsar Ramsar (The Convention on Wetlands of International Importance, especially as Waterfowl Habitat), yaitu perjanjian internasional untuk konservasi dan pemanfaatan lahan basah secara berkelanjutan menetapkan beberapa calon situs untuk dijadikan situs Ramsar berdasarkan pentingnya perlindungan lahan basah yang dimiliki. Di Pulau Rambut terdapat lahan basah berupa rawa, lahan gambut, situ, sungai, dan pesisir. Di Pulau Rambut juga terdapat beberapa habitat lahan basah lainnya diantaranya terumbu karang, lamun dan hutan mangrove. Pulau Rambut juga merupakan tempat transit burung-burung bermigrasi dari bumi belahan utara menuju Australia terutama pada bulan Oktober hingga Desember yang mana terdapat sekitar 15 jenis mangrove yang dijadikan tempat reproduksi (breeding habitat) bagi banyak spesies burung (Anon, 2012). Sehingga dinamika yang terjadi pada hutan mangrove di Pulau Rambut akan berakibat pada kelangsungan burung yang ada di Pulau Rambut tersebut. 
Tulisan ini bertujuan untuk melakukan pemetaan dinamika luas hutan mangrove di Pulau Rambut dari tahun 2010 hingga 2017 menggunakan citra satelit resolusi tinggi yang diperoleh secara gratis dari Google Earth yaitu citra satelit GeoEye 1, dan foto udara hasil pemotretan menggunakan UAV tipe quadcopter yaitu DJI Phantom 3 Pro, yang diintegrasikan secara terpadu ke dalam suatu Sistem Informasi Geografis.

\section{BAHAN DAN METODE}

Lokasi penelitian di Pulau Rambut berada di Kelurahan Untung Jawa, Kecamatan Kepulauan Seribu Selatan, Kabupaten Kepulauan Seribu. Berjarak sekitar 4,2 km dari daratan Pulau Jawa atau $21 \mathrm{~km}$ sebelah barat laut dari Pelabuhan Marina dengan luas sekitar 42,6 hektar. Data dinamika hutan mangrove minimal memerlukan 2 periode waktu yang berbeda. Pada penelitian ini data yang digunakan adalah data citra satelit GeoEye 1 tanggal akuisisi 31 Juli 2010 yang diunduh dari Google earth, dan data foto udara hasil akuisisi tanggal 13-14 November 2017. Citra satelit GeoEye 1 pada Google earth Pro dilakukan zooming secara maksimal terhadap daerah penelitian. Pilihan resolusi dipilih yang paling maksimal yaitu berukuran 4800 x 2890 sehingga untuk seluruh Pulau Rambut diperoleh citra sebanyak 9 (sembilan) buah. Proses mosaicking selanjutnya dilakukan untuk menggabungkan 9 citra tersebut. Hasilnya diperoleh sebuah citra mosaic berukuran 5949 $\mathrm{x}$ 8045. Proses georektifikasi selanjutnya dilakukan untuk meregistrasi citra mosaic sehingga memiliki koordinat bumi, dalam hal ini dipilih sistem koordinat UTM zona 48 dengan datum WGS 84.

Adapun untuk akusisi foto udara diperlukan beberapa tahapan, yaitu tahap persiapan, tahap akuisisi dan tahap pengolahan data. Pada tahap persiapan dilakukan identifikasi luasan area yang akan dipetakan dalam satuan hektar. Ditentukan juga resolusi piksel atau ground sample distance (GSD) yang diinginkan. Untuk ketinggian 100 meter dihasilkan GSD sebesar $4,43 \mathrm{~cm}$. Besaran overlap antar foto ditentukan sebesar $80 \%$ dikarenakan relief vegetasi yang bervariasi. Wahana yang digunakan adalah drone tipe DJI Phantom 3 Pro dengan resolusi kamera sebesar 12 MP dengan kemampuan terbang selama 15 menit tiap baterainya. Selanjutnya digunakan Pix4D Capture yaitu sebuah aplikasi berbasis Android digunakan untuk mengestimasi jumlah dan lamanya terbang berdasarkan parameter tersebut sehingga diperoleh informasi diperlukan sebanyak 4 (empat) kali terbang (Gambar.1).

Pemasangan benchmark untuk kepentingan georektifikasi selanjutnya dilakukan. Benchmark merupakan penanda di atas permukaan bumi yang dapat diketahui koordinatnya secara akurat. Adapun benchmark terbuat dari bahan yang tahan cuaca dan dapat terlihat oleh drone. Koordinat benchmark kemudian diperoleh menggunakan GPS Geodetik

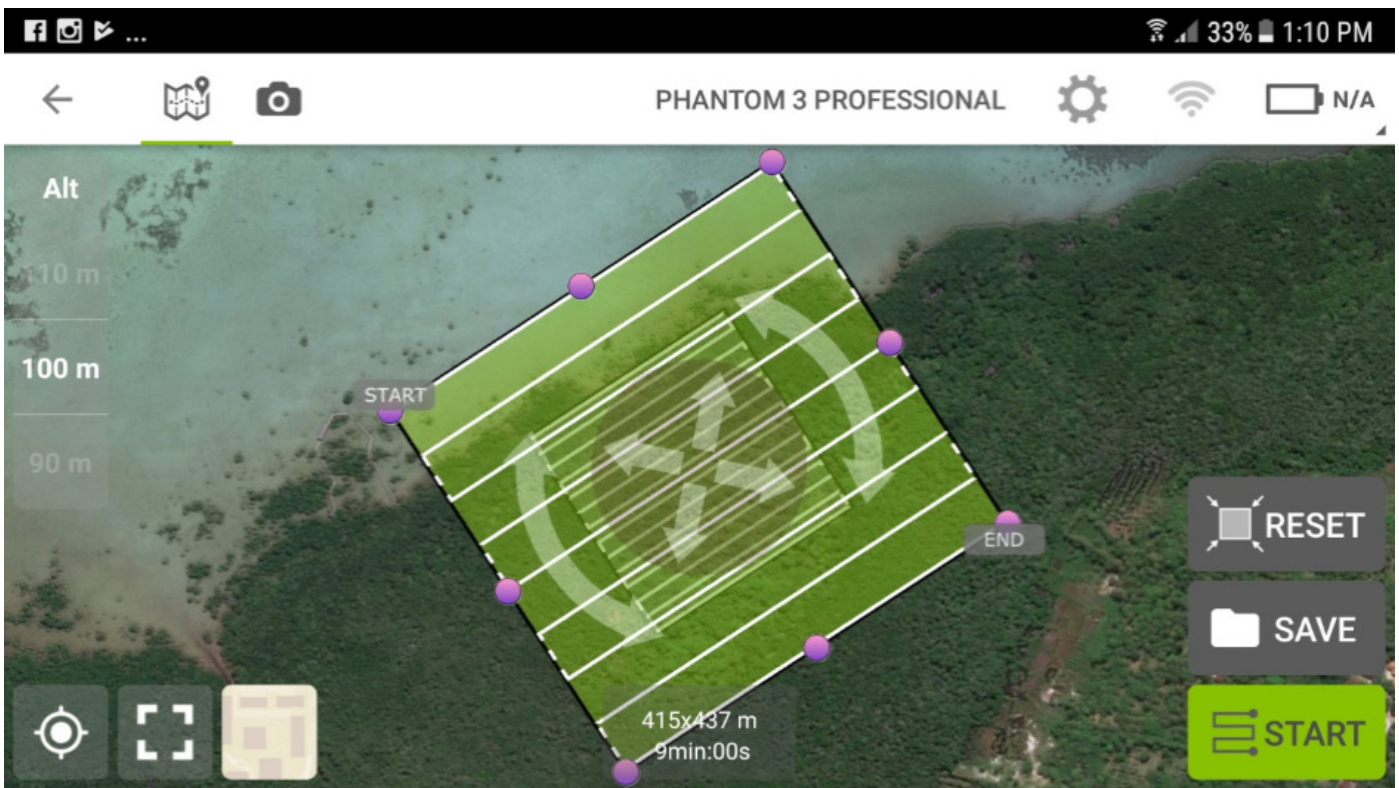

Gambar 1. Tampilan pada aplikasi Pix4D Capture yang menunjukkan jumlah dan jalur terbang, ketinggian terbang, area yang tercover dan perkiraan durasi pemotretan foto udara.

Figure 1. Appearance on Pix4D Capture app showing number of flight and path, fly height, covered area and approximate of aerial photo acquisition duration.

Pemetaan Dinamika Hutan Mangrove Menggunakan Drone dan Penginderaan Jauh di P. Rambut, Kepulauan Seribu Hadiwijaya Lesmana Salim, Restu Nur Afi Ati1 dan Terry Louise Kepel 
dengan ketelitian maksimal $0,5 \mathrm{~cm}$ (Gambar 2). Koordinat tersebut merupakan Ground Control Point (GCP) yang nantinya akan digunakan untuk georektifikasi. Tahap berikutnya adalah tahap akuisisi foto udara. Waktu pengambilan foto sekitar jam 08:00 sampai jam 10:30 dan jam 14:00 sampai jam 16:30 dengan asumsi cuaca cerah dan angin tidak berhembus kencang.

Foto udara yang diperoleh kemudian dipilih. Fotofoto yang blur, miring ataupun sudut yang tidak tegak $90^{\circ}$ disisihkan sehingga diperoleh foto yang siap diolah sebanyak 499 buah foto. Pengolahan data foto udara yang diperoleh menggunakan software Pix4D Mapper versi trial. Dalam tahap ini dilakukan proses aligning photo, build dense cloud, texturing, orthomosaicking, build DSM hingga exporting peta ortho. Align photo adalah proses mensejajarkan atau meluruskan foto-foto sebelum proses penggabungan banyak foto menjadi suatu foto. Adapun build dense cloud memproses foto hasil alignment menjadi banyak titik yang memiliki nilai ketinggian atau kedalaman. Texturing merubah data yang berbentuk titik menjadi tekstur atau kekasaran dari permukaan bumi. Orthomosaicking merupakan proses menggabungkan foto-foto berdasarkan referensi koordinat dan nilai kedalaman piksel. Adapun Digital Surface Model (DSM) merupakan model tinggi rendahnya obyek di permukaan bumi hasil proses orthomosaic yang selanjutnya akan diekspor ke dalam format tiff. Peta yang dihasilkan selanjutnya menggunakan software pengolah citra untuk compressing data dan exorting menjadi format ecw agar ukuran file bisa lebih kecil. Data citra Geoeye dan foto udara selanjutnya dilakukan proses klasifikasi penggunaan lahan. Metode yang digunakan berupa interpretasi visual dengan cara digitizing on-screen dan klasifikasi berdasarkan objek (Geobia) menggunakan software versi trial yaitu eCognition, yang dapat diunduh di http:// www.ecognition.com/free-trial. Metode Geobia tersebut mensegmentasikan foto udara yang sudah diorthomosaik berdasarkan warna, tekstur, bentuk dan kedekatan objek. Pendekatan ini termasuk hal baru dan lebih unggul jika dibandingkan dengan pendekatan berbasis piksel untuk klasifikasi citra (Wibowo \& Suharyadi, 2012). Hasil klasifikasi selanjutnya diexport ke dalam format shp agar dapat diolah di software GIS. Adapun parameter segmentasi untuk citra GeoEye 1 dan foto udara untuk algoritma multispectral scale parameter sebesar 100 , shape 0,2 dan compactness sebesar 0,5 serta algoritma maximum spectral difference sebesar 1 untuk citra GeoEye 1 dan 5 untuk foto udara. Software GIS digunakan untuk mengolah file vector tersebut. File shp tersebut dilakukan merging region (dissolve) untuk kelas yang sama. Konversi koordinat dari geografik menjadi UTM selanjutnya dilakukan agar dapat diperoleh informasi luasan kelas penggunaan lahan.

Uji akurasi selanjutnya dilakukan untuk mengetahui ketelitian hasil klasifikasi tutupan lahan. Metode yang digunakan menggunakan metode matriks kesalahan (confussion matrix). Pengambilan titik uji akurasi dilakukan melalui survei lapangan dan

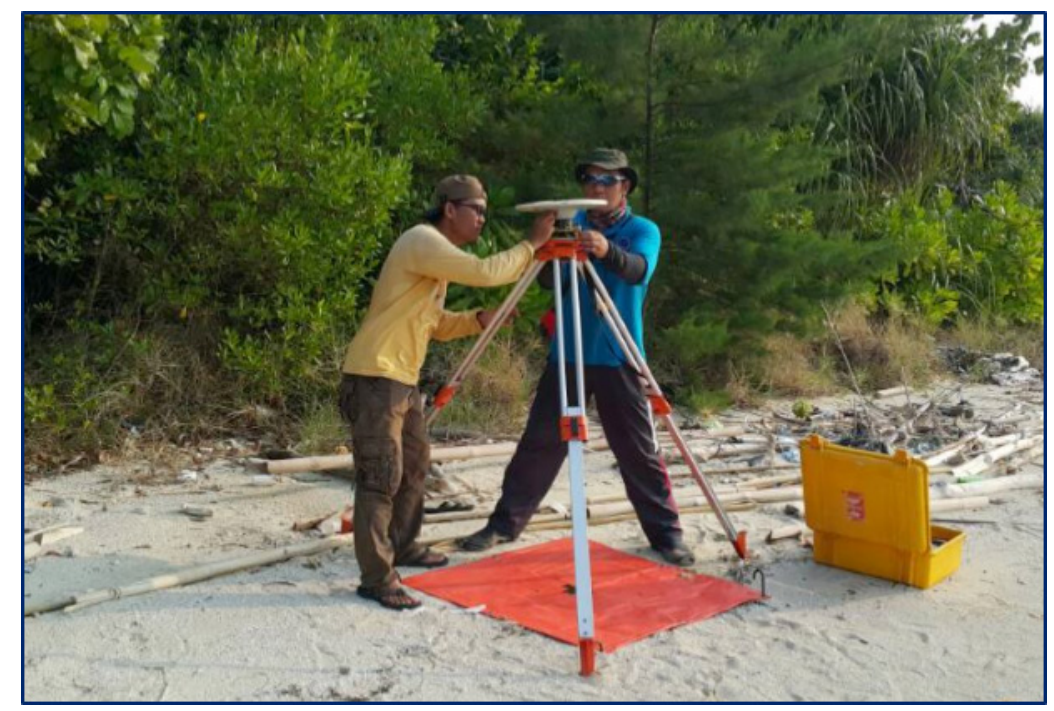

Gambar 2. Pengambilan koordinat (GCP) menggunakan GPS Geodetik di atas benchmark. Figure 2. GCP Coordinate retrieval using Geodetic GPS on benchmarks.

JURNAL KELAUTAN NASIONAL, Vol. 13, No 2, Agustus 2018, Hal. 89-97 
dengan menginterpretasi objek pada foto udara dan citra GeoEye 1. Titik uji tersebar merata di lokasi penelitian dengan sistem grid yang berukuran 40 x 40 meter, yang mana tiap titik diidentifikasi secara visual kelas tutupan lahannya. Luas pulau Rambut sekitar 42 hektar selanjutnya dibagi dengan grid 40 x 40 meter sehingga diperoleh jumlah titik uji sebanyak 271 titik untuk tahun 2010 dan sebanyak 264 titik untuk tahun 2017. Perubahan jumlah titik uji tersebut disebabkan karena terjadinya perubahan luas Pulau Rambut yang berkurang sekitar 1 hektar. Menurut Ramadhani (2015) interpretasi visual sangat dimungkinkan pada citra resolusi spasial sangat tinggi. Pada penelitian ini citra GeoEyel (resolusi pasial $0,46 \mathrm{~m}$ ) dan foto udara $(0,04$ m) merupakan citra resolusi sangat tinggi. Informasi tutupan lahan hasil klasifikasi GEOBIA pada titik uji diperoleh dengan cara ekstraksi peta tutupan lahan. Informasi pada titik uji tersebut kemudian disusun menjadi sebuah matriks kesalahan. Hasil matriks tersebut akan diketahui akurasi klasifikasi keseluruhan (overall accuracy), akurasi pengguna (user accuracy) dan akurasi pembuat (producer accuracy), juga akan diketahui nilai koefisien kappa-nya. Akurasi keseluruhan diartikan sebagai total kelas yang diklasifikasikan dibagi dengan total kelas referensi. Adapun akurasi pengguna merupakan elemen yang diklasifikasikan secara benar untuk setiap kategori dibagi dengan total elemen yang diklasifikasikan kedalam kategori tersebut. Sedangkan akurasi pembuat merupakan jumlah elemen kelas yang diklasifikasikan secara benar dibagi dengan elemen referensi untuk kategori.

\section{HASIL DAN PEMBAHASAN}

Hasil citra satelit GeoEye 1 dan mosaik foto udara yang sudah tergeoreferens tersaji pada Gambar 3. GSD foto udara yang diperoleh adalah sebesar $4,43 \mathrm{~cm}$ sehingga kejelasan dan kedetailan informasi yang diperoleh dapat terlihat lebih jelas dibandingkan dengan citra GeoEye 1 yang mempunyai resolusi sebesar 0,46 meter. Garis pantai, vegetasi dan bayangan pepohonan terlihat jelas pada foto udara, sehingga dapat membantu dalam proses klasifikasi visual. Begitu juga dengan penampakkan dasar perairan dangkal, dapat terlihat dengan jelas.

Interpretasi mangrove di Pulau Rambut pada citra satelit dan foto udara perlu memperhatikan 9 kunci interpretasi yaitu rona atau warna, ukuran, bentuk, tekstur, pola, tinggi, bayangan, situs, dan asosiasi (Sutanto, 1986). Rona atau warna mangrove akan terlihat lebih hijau dan gelap karena mengrove biasanya berada di sedimen yang basah dan sifat air yang menyerap banyak gelombang elektromagnetik dan sedikit memantulkan. Tekstur mangrove akan terlihat lebih kasar dibandingkan semak atau rerumputan. Secara situs, mangrove akan terletak di pinggir pantai atau pinggir sungai dikarenakan membutuhkan air. Hasil interpretasi menunjukkan bahwa vegetasi mangrove tesebar di bagian utara dan timur Pulau Rambut dan sebagian kecil di bagian barat. Pada
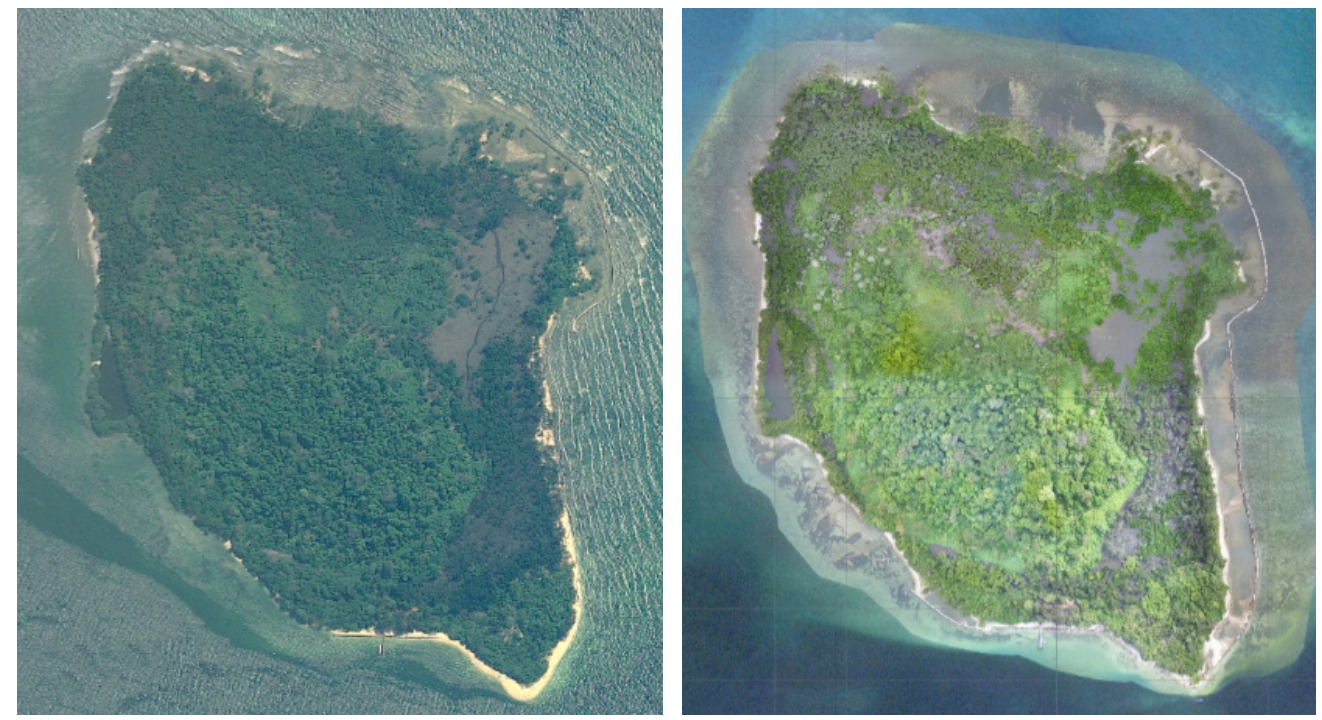

Gambar 3. Citra satelit GeoEye 1 akuisisi 31 Juli 2010 (kiri) dan data foto udara hasil akuisisi 11-12 November 2017 (kanan).

Figure 3. GeoEye 1 satellite image acquisited on July 31, 2010 (left) and aerial photographs of acquisition results on 11-12 November 2017 (right).

Pemetaan Dinamika Hutan Mangrove Menggunakan Drone dan Penginderaan Jauh di P. Rambut, Kepulauan Seribu - 

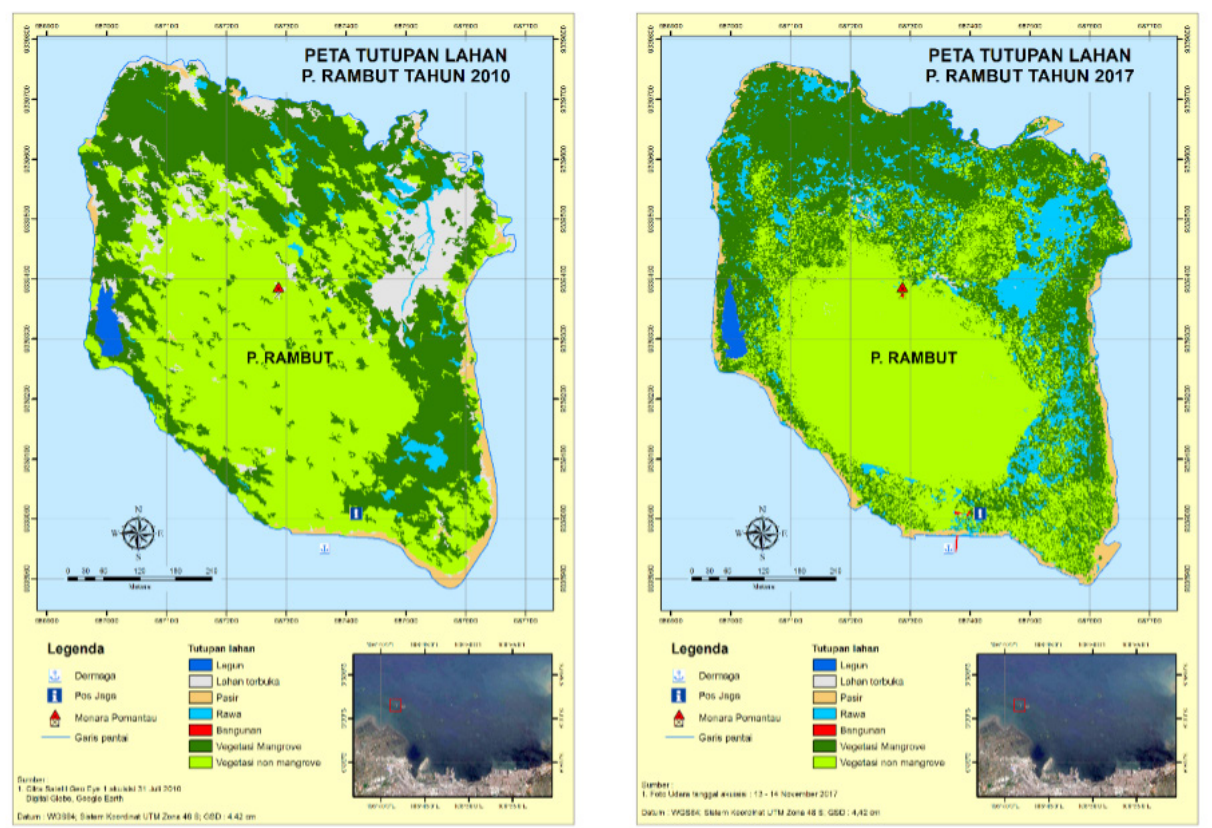

Gambar 4. Perbandingan tutupan lahan di Pulau Rambut tahun 2010 (kiri) dan tahun 2017 (kanan).

Figure 4. Comparison of land cover on Pulau Rambut in 2010 (left) and 2017 (right).

tahun 2017 luas hutan mangrove sebesar 17,48 hektar sedangkan di tahun 2010 seluas 16,73 hektar atau ada penambahan luas sebesar 0,75 hektar. Penambahan luasan areal mangrove diduga dikarenakan oleh adanya dinding pantai (revetment) yang dibangun sejak tahun 2010 di sebelah timur dan selatan pulau, sehingga efektif mampu menghalangi proses abrasi. Terlebih lagi semenjak ditetapkannya Pulau Rambu sebagai situs Ramsar, upaya-upaya perlindungan kelestarian menjadi lebih terjaga.

Adapun daerah tergenang tahun 2017 lebih luas dibandingkan dengan tahun 2010 diduga karena waktu pemotretan merupakan waktu musim penghujan dan air laut sedang pasang naik. Sedangkan pada tahun 2010 merupakan waktu musim kemarau yaitu bulan Juli (Gambar 4).

Klasifikasi tutupan lahan dari hasil analisis digital berbasis objek menunjukkan hasil yang cukup baik dengan akurasi keseluruhan sebesar $75,6 \%$ untuk tahun 2010 dan 77,3\% untuk tahun 2017. Matriks kesalahan, akurasi pengguna dan akurasi pembuat pada masingmasing kelas dapat dilihat pada Tabel 1. dan Tabel 2.

Pada tahun 2010, akurasi pemetaan yang paling tinggi ditemukan pada kelas lagun dan vegetasi non-mangrove. Pada kelas lagun seluruh objek yang diklasifikasikan

Tabel 1. Luasan sebaran sedimentasi

Table 1. Extent of Sedimentation Distribution

\begin{tabular}{|c|c|c|c|c|c|c|c|c|c|}
\hline JENIS & Lagun & $\begin{array}{l}\text { Lahan } \\
\text { terbuka }\end{array}$ & Pasir & Rawa & Bangunan & Mangrove & $\begin{array}{l}\text { Vegetasi } \\
\text { non- } \\
\text { mangrove }\end{array}$ & Total & $\begin{array}{l}\text { Prod } \\
\text { acc. }\end{array}$ \\
\hline Lagun & 1 & 0 & 0 & 0 & 0 & 1 & 0 & 2 & $50 \%$ \\
\hline Lahan terbuka & 0 & 11 & 2 & 0 & 0 & 9 & 5 & 27 & $41 \%$ \\
\hline Pasir & 0 & 0 & 5 & 0 & 0 & 1 & 0 & 6 & $83 \%$ \\
\hline Rawa & 0 & 1 & 0 & 0 & 0 & 2 & 0 & 3 & $0 \%$ \\
\hline Bangunan & 0 & 0 & 0 & 0 & 0 & 0 & 0 & 0 & $0 \%$ \\
\hline Mangrove & 0 & 1 & 0 & 0 & 0 & 83 & 22 & 106 & $78 \%$ \\
\hline $\begin{array}{l}\text { Vegetasi non- } \\
\text { mangrove }\end{array}$ & 0 & 3 & 0 & 0 & 0 & 19 & 105 & 127 & $83 \%$ \\
\hline Total & 1 & 16 & 7 & 0 & 0 & 115 & 132 & 271 & \\
\hline User acc. & $100 \%$ & $69 \%$ & $71 \%$ & $0 \%$ & $0 \%$ & $72 \%$ & $80 \%$ & & \\
\hline
\end{tabular}

Sumber : Hasil Pengolahan

JURNAL KELAUTAN NASIONAL, Vol. 13, No 2, Agustus 2018, Hal. 89-97 
sebagai lagun sesuai dengan data referensi (100\%). Adapun pada kelas vegetasi non-mangrove terjadi kesalahan klasifikasi yaitu pada mangrove dikarenakan warna dan tekstur yang hampir sama sedangkan kesalahan pada lahan-lahan terbuka karena ukuran segmen yang lebih besar dari seharusnya. Sedangkan untuk klasifikasi mangrove terjadi kesalahan sebagian besar pada vegetasi non-mangrove karena warna mangrove yang berbatasan dengan vegetasi nonmangrove hampir sama. Begitu juga kesalahan pada lahan terbuka dikarenakan ukuran segmen mangrove yang lebih besar dari ukuran sebenarnya di lapangan. Kesalahan tersebut dapat diminimalisir dengan mengecilkan nilai segmentasi, terutama pada analisis foto udara yang memiliki resolusi $4,3 \mathrm{~cm}$. Sehingga semakin kecil nilai segmentasi maka akan semakin detail obyek yang akan diidentifikasi. Nilai koefisien kappa yang diperoleh untuk tahun 2010 adalah sebesar 0,61 atau menurut Altman (1991) termasuk ke dalam ketegori kuat (good).

Hasil klasifikasi foto udara tahun 2017 menunjukkan akurasi yang tinggi. Adapun nilai koefisien kappa sebesar 0,62, menunjukkan adanya kesepakatan yang erat (strength of agreement) antara model analisis GeoBIA dengan hasil pengukuran lapangan. Akurasi pemetaan yang paling tinggi ditemukan pada kelas lagun $(100 \%)$ dan pasir $(100 \%)$, artinya pada kelaskelas tersebut seluruh objek yang diklasifikasikan sesuai dengan data referensi. Akurasi tertinggi berikutnya berada pada kelas rawa meskipun demikian di beberapa titik uji terjadi kesalahan interpretasi yaitu pada mangrove. Hal tersebut karena terdapat ukuran mangrove yang lebih kecil di atas rawa sehingga tidak tersegmentasi dengan baik. Sedangkan pada kelas mangrove terjadi kesalahan di beberapa titik yaitu pada vegetasi non-mangrove dan rawa. Hal tersebut diduga dikarenakan adanya kemiripan warna vegetasi dengan mangrove akibat perbedaan waktu akuisisi foto udara dan kondisi cuaca yang berbeda cuaca sehingga terjadi perbedaan rona dan warna pada kelas yang sama. Kesalahan pada rawa dimungkinkan karena adanya bayangan vegetasi mangrove pada rawa sehingga dikelaskan menjadi mangrove.

Berdasarkan nilai uji akurasi yang diperoleh maka dapat dinyatakan bahwa penggunaan foto udara akan lebih baik dalam hal ketelitian dan ketepatan klasifikasi. Semakin tinggi resolusi spasial suatu citra maka akan semakin tinggi akurasi identifikasi objeknya. Adapun menurut nilai koefisien kappa baik tahun 2010 maupun 2017, menunjukkan keeratan yang kuat (good) antara model analisis menggunakan GeoBIA dibandingkan dengan hasil kenyataan di lapangan

Data dari Pusat Riset Kelautan (2017) menunjukkan bahwa simpanan karbon rata-rata yang ada di Pulau Rambut adalah sebesar 77,41 Mg/ha, sehingga diestimasi total kandungan karbon di Pulau Rambut pada 2017 adalah sebesar 1.353,1 MgC atau euivalen sebesar 4.961,4 $\mathrm{Mg} \mathrm{Co}_{2}$. Adapun dalam kurun waktu 7 tahun, di Pulau Rambut terjadi peningkatan penyerapan karbon dioksida sebesar 212,8 $\mathrm{Mg} \mathrm{Co}_{2}$. Angka tersebut berasal dari perhitungan biomassa dan tidak memasukkan data serapan karbon yang ada di sedimen mangrovenya. Nilai serapan karbon di Pulau Rambut lebih kecil jika dibandingkan dengan yang ada di Kabupaten Indragiri Hilir yaitu sebesar 159, 46 $\mathrm{Mg} / \mathrm{ha}$ (Restuhadi et al., 2013). Kecilnya nilai serapan karbon di Pulau Rambut diduga dikarenakan oleh

Tabel 2. Luasan sebaran sedimentasi

Table 2. Extent of Sedimentation Distribution

\begin{tabular}{|c|c|c|c|c|c|c|c|c|c|}
\hline JENIS & Lagun & $\begin{array}{l}\text { Lahan } \\
\text { terbuka }\end{array}$ & Pasir & Rawa & Bangunan & Mangrove & $\begin{array}{l}\text { Vegetasi } \\
\text { non } \\
\text { mangrove }\end{array}$ & Total & $\begin{array}{l}\text { Prod } \\
\text { acc. }\end{array}$ \\
\hline Lagun & 3 & 0 & 0 & 0 & 0 & 0 & 0 & 3 & $100 \%$ \\
\hline Lahan terbuka & 0 & 0 & 0 & 0 & 0 & 0 & 0 & 0 & $0 \%$ \\
\hline Pasir & 0 & 0 & 1 & 0 & 0 & 1 & 0 & 2 & $50 \%$ \\
\hline Rawa & 0 & 3 & 0 & 17 & 0 & 7 & 1 & 28 & $61 \%$ \\
\hline Bangunan & 0 & 0 & 0 & 0 & 0 & 0 & 0 & 0 & $0 \%$ \\
\hline Mangrove & 0 & 0 & 0 & 4 & 0 & 82 & 29 & 115 & $71 \%$ \\
\hline $\begin{array}{l}\text { Vegetasi } \\
\text { non-mangrove }\end{array}$ & 0 & 0 & 0 & 0 & 0 & 15 & 101 & 116 & $87 \%$ \\
\hline Total & 3 & 3 & 1 & 21 & 0 & 105 & 131 & 264 & \\
\hline User acc. & $100 \%$ & $0 \%$ & $100 \%$ & $81 \%$ & $0 \%$ & $78 \%$ & $77 \%$ & & \\
\hline
\end{tabular}

Sumber : Hasil Pengolahan 
ukuran diameter pohon mangrove yang kecil. Besar atau kecilnya diameter pohon dipengaruhi oleh besar atau kecilnya kandungan selulosa dan zat ekstraktif serta senyawa polisakarida lainnya yang tersimpan pada batang (Hilmi, 2003).

Perhitungan nilai ekonomi hutan mangrove di Pulau Rambut, jika diasumsikan kondisinya sama dengan kondisi di Teluk Kotania Seram Barat yaitu sebesar Rp. 60,9 juta per hektar (Supriyadi \& Wouthuyzen, 2005) maka harga ekonomi hutan mangrove di Pulau Rambut sebesar Rp. 1,06 milyar di tahun 2017.

\section{KESIMPULAN DAN SARAN}

Data foto udara resolusi sangat tinggi dengan GSD sebesar 4,43 cm dan citra satelit geoEye 1 resolusi $0,46 \mathrm{~m}$ yang digunakan dalam penelitian ini, dengan metode segmentasi dan klasifikasi terbimbing dan data pengamatan lapangan, dapat mengetahui dinamika sebaran dan luasan mangrove dengan mudah dan dapat dipetakan secara detail. Luasan hutan mangrove yang ditemukan di Pulau Rambut adalah sebesar 16,73 ha pada tahun 2010 dan 17,48 ha pada tahun 2017 atau terjadi penambahan sebesar 0,75 hektar dalam kurun waktu 7 tahun. Hutan mangrove yang ditemukan di lokasi tersebut didominasi oleh Rhizophora apiculata Rhizophora mucronata. Hasil akurasi keseluruhan adalah sebesar 75,6\% untuk tahun 2010 dan 77,3\% untuk tahun 2017 dengan nilai koefisien kappa sebesar 0,61 untuk tahun 2010 dan 0,62 untuk tahun 2017. Penggunaan foto udara menghasilkan peta tutupan lahan yang lebih akurat dan detail jika dibandingkan dengan citra satelit GeoEye 1.

\section{UCAPAN TERIMA KASIH}

Penelitian ini dibiayai oleh DIPA Pusat Riset Kelautan, BRSDMKP Tahun Anggaran 2017, oleh karenanya penulis ingin mengucapkan terimakasih kepada bapak Riyanto Basuki selaku Kepala Pusat Riset Kelautan. Penulis juga berterima kasih kepada kelompok Karbon Biru atas bantuan dan masukan diskusinya. Terima kasih yang sama juga bagi Balai Konservasi Sumberdaya Alam (BKSDA) DKI Jakarta atas dimudahkannya perizinan dan dukungan personel selama kunjungan lapang.

\section{DAFTAR PUSTAKA}

Altman D.G. (1991), Practical Statistics for Medical Research. London: Chapman and Hall, https://www. medcalc.org/manual/kappa.php diakses pada 10
Januari 2018

Amelia, N. R., Akhbar. \& Arianingsih, I. (2015), Pembuatan Peta Penutupan Lahan Menggunakan Foto Udara yang Dibuat dengan Paramotor di Taman Nasional Lore Lindu (Tnll) (Studi Kasus Desa Pakuli Kecamatan Gumbasa Kabupaten Sigi), Warta Rimba Vol.3 No.2: 65-72.

Annonymous, 2012, Indonesia's newest Ramsar Site, https:// www.ramsar.org/news/indonesias-newest-ramsarsite diakses pada 8 Januari 2018

Gularso, H., Subiyanto, S. \& Sabri, L. M. (2013), Tinjauan Pemotretan Udara Format Kecil Menggunakan Pesawat ModelSkywalker 1680 (Studi Kasus: Area Sekitar Kampus UNDIP), Jurnal Geodesi Undip, Vol.2 No.2 :78-94.

Hilmi, E. (2003). Model penduga kandungan karbon pada pohon kelompok jenis Rhizophora spp dan Bruguiera spp dalam tegakan hutan mangrove (Studi Kasus di Indragiri Hilir Riau). [disertasi]. Bogor: Program Pascasarjana, Institut Pertanian Bogor

Huisman, O. \& Rolf, A. De. By. (2009). Principles of Geographic Information System - An Introductory Textbook, ITC, Enschede, The Netherlands

Lo, C. P. (1995). Penginderaan Jauh Terapan. Universitas Indonesia Press, Jakarta

Muhammad. (2014). Pemetaan Perubahan Penggunaan Lahan di Kecamatan Sewon Kabupaten Bantul Tahun 1999-2006 dengan Citra Satelit Ikonos. Laporan Tugas Akhir, Fakultas Geografi UGM, Yogyakarta

Onrizal \& Kusmana, C. (2006). Komposisi Jenis dan Struktur Hutan Mangrove di Suaka Margasatwa Pulau Rambut, Teluk Jakarta. Peronema Forestry Science Journal Vol 2(1): 1-7.

Puntodewo, A., Dewi, S., \& Tarigan, J. (2003) Sistem Informasi Geografis Untuk Pengelolaan Sumberdaya Alam, Center for Internaional Forestry Research (CIFOR), Bogor, https://www.cifor.org/publications/ pdf_files/books/SIGeografis/SIG-part-4.pdf diakses pada 8 Januari 2018

Purbowaseso, B. (1995). Penginderaan Jauh Terapan, UI Press, Jakarta.

Pusat Riset Kelautan (2017). Kajian Dinamika Ekosistem Pesisir dalam Kerangka Mitigasi dan Adaptasi Perubahan Iklim. Laporan Akhir Kegiatan, Badan Riset dan Sumberdaya Manusia Kelautan dan Perikanan, KKP.

Ramadhani, Y. H., Rokhmatulloh, Poniman, A. \& Susanti, R. (2015). Pemetaan Pulau Kecil dengan Pendekatan Berbasis Objek Menggunakan Data Unmanned Aerial Vehicle (UAV) Studi Kasus di Pulau Pramuka, Kepulauan Seribu, Majalah Ilmiah Globe, Vol.17 No.2 : 125 -134.

Restuhadi, F., Sandhyavitri, A., Sulaeman, R., Kurnia, D. \& Suryawan, I. (2013). Estimasi Potensi Cadangan Karbon Hutan Mangrove: Studi Kasus di Kabupaten Indragiri Hilir. ISBN 978-602-9066-67-8, Pusat Pengembangan Pendidikan, Universitas Riau, Pekanbaru 
Septiana, B., Wijaya, A. P. \& Suprayogi, A. (2017), Analisis Perbandingan Hasil Orthorektifikasi Metode Range Doppler Terrain Correction dan Metode Sar Simulation Terrain Correction Menggunakan Data Sar Sentinel - 1, Jurnal Geodesi Undip, Vol.6 No.1, 148-157.

Sitorus, J., Purwandari, Darwini, L. E., Widyastuti, R. \& Suharno. (2006). Kajian Model Deteksi Perubahan Penutup Lahan Menggunakan Data Inderaja untuk Aplikasi Perubahan Lahan Sawah. www.lapanrs.com Somantri, L. (2008), Pemanfaatan Teknik Penginderaan Jauh untuk Mengidentifikasi Kerentanan dan Risiko Banjir, Jurnal Geografi GEA, Vol. 8 No. 2, http://ejournal.upi. edu/index.php/gea/article/view/1697/1148 diakses pada 8 Januari 2018

Suprakto, B. (2005), Studi tentang Dinamika Mangrove Kawasan Pesisir Selatan Kabupaten Pamekasan Provinsi Jawa Timur dengan Data Penginderaan Jauh, Prosiding Pertemuan Ilmiah Tahunan MAPIN XIV. Institut Teknologi Sepuluh Nopember.

Supriyadi, I. H., \& Wouthuyzen, S. (2005). Penilaian ekonomi sumberdaya Mangrove di Teluk Kotania Seram Barat, Provinsi Maluku, OLDI (38) 1-21.

Sutanto. (1986). Penginderaan Jauh Jilid I. Yogyakarta: Gadjah Mada University Press.

Suwargana, N. (2008), Analisis Perubahan Hutan Mangrove Menggunakan Data Penginderaan Jauh di Pantai Bahagia, Muara Gembong, Bekasi, Jurnal Penginderaan Jauh, Vol.5:64-74.

Wahyunto. (2007), Peranan Citra Satelit dalam Penentuan Potensi Lahan. www.litbang.deptan.go.id

Wibowo, T. S. \& Suharyadi, R. (2012). Aplikasi ObjectBased Image Analysis (OBIA) untuk Deteksi Perubahan Penggunaan Lahan Menggunakan Citra ALOS AVNIR-2, Jurnal Bumi Indonesia, Volume 1, No. $3: 130-138$. 
